\title{
The Job Demands-Resources model as predictor of work identity and work engagement: A comparative analysis
}

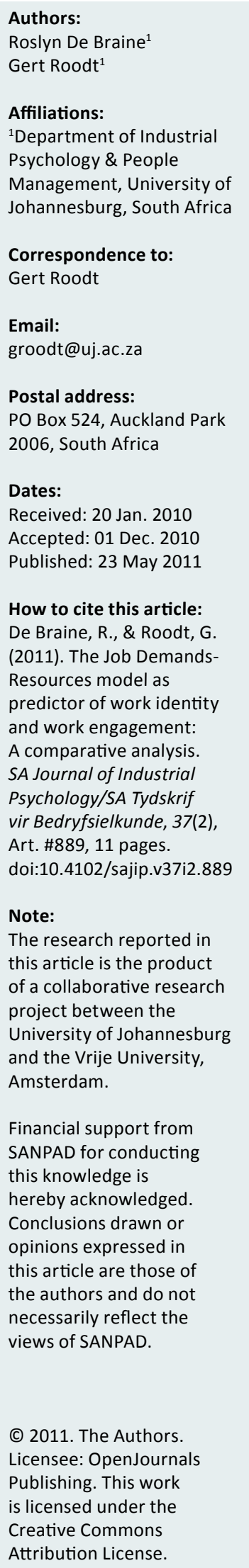

Orientation: Research shows that engaged employees experience high levels of energy and strong identification with their work, hence this study's focus on work identity and dedication.

Research purpose: This study explored possible differences in the Job Demands-Resources model (JD-R) as predictor of overall work engagement, dedication only and work-based identity, through comparative predictive analyses.

Motivation for the study: This study may shed light on the dedication component of work engagement. Currently no literature indicates that the JD-R model has been used to predict work-based identity.

Research design: A census-based survey was conducted amongst a target population of 23134 employees that yielded a sample of 2429 (a response rate of about 10.5\%). The Job DemandsResources scale (JDRS) was used to measure job demands and job resources. A work-based identity scale was developed for this study. Work engagement was studied with the Utrecht Work Engagement Scale (UWES). Factor and reliability analyses were conducted on the scales and general multiple regression models were used in the predictive analyses.

Main findings: The JD-R model yielded a greater amount of variance in dedication than in work engagement. It, however, yielded the greatest amount of variance in work-based identity, with job resources being its strongest predictor.

Practical/managerial implications: Identification and work engagement levels can be improved by managing job resources and demands.

Contribution/value-add: This study builds on the literature of the JD-R model by showing that it can be used to predict work-based identity.

\section{Introduction}

Dedicated employees are usually enthusiastic, inspired and have a strong identification towards their work. Such employees are regarded as being highly engaged in what they do. Dedication is regarded as one dimension of work engagement, alongside the other dimensions of work engagement, which are vigour and absorption (Bakker, Schaufeli, Leiter \& Taris, 2008). Of these three dimensions dedication is considered to be too broadly conceptualised (Shirom, 2004), due to the overlap of its meaning with identification, work-based identity and job involvement, which is detailed later in the article.

Dedication refers to 'being strongly involved in one's work and experiencing a sense of significance, enthusiasm, and challenge' (Bakker \& Demerouti, 2008, p. 210). It is also regarded as the opposite of cynicism - a dimension of burnout (González-Romá, Schaufeli, Bakker \& Lloret, 2006). Consequently, work engagement is seen as the opposite pole of burnout along two distinct underlying sub-constructs termed 'energy and identification' (González-Romá et al., 2006). Energy and identification are depicted as two continuums between work engagement (respectively vigour and dedication) and burnout (respectively exhaustion and cynicism) as the opposite ends of these continua. Dedication and cynicism therefore form the extreme ends of the identification continuum. Very little is known about the nature and development of this identification continuum. This requires more empirical investigation (González-Romá et al., 2006; Hakanen \& Roodt, 2010).

As stated earlier, dedication bears some overlap in its conceptualisation with identification, job involvement and work-based identity. In a meta-analysis of work engagement, it is described 
as 'an identification-based component of engagement' (Halbesleben, 2010, p.110). This relationship that work engagement has with identification stems from the early conceptualisations of engagement by Kahn (1990). Kahn (1990, p. 694) conceptualised engagement at work as the harnessing of organisational members' selves to their work roles'. Kahn (1992) later argued that engaged employees experience psychological presence in their work that becomes integrated into their identity. This definition of engagement has some resemblance to the definition of work identity by Walsh and Gordon (2007) that:

an individual's work identity refers to a work-based self-concept, constituted of a combination of organisational, occupational, and other identities that shapes the roles a person adopts and the corresponding ways he or she behaves when performing his or her work.

(Walsh \& Gordon, 2007, p. 2)

Although at first glance, the definition of work identity may seem different from Kahn's definition of engagement, a closer investigation shows that they share some similarity in that they both refer to different identities or 'selves' and work roles.

The definition of work engagement by Bakker and Leiter (2010, p. 188) also provides a different understanding of dedication, as they include both involvement and identification in its definition. Work engagement is defined as 'a subjective experience with two core dimensions: energy and involvement/identification' (p. 188). In an earlier study, dedication has been defined as 'strong involvement that goes one step further than the usual level of identification' (Schaufeli, Salanova, González-Romá \& Bakker, 2002, p. 74). This relationship of identification with job involvement stems from Lodahl and Kejner's (1965, p. 24) definition of job involvement 'as the degree to which a person is identified psychologically with his work, or the importance of work in his work self-image' and Kanungo's (1982) description of job involvement as psychological identification with one's work or one's job. In both explanations of job involvement there is a degree of overlap with the definition of work identity, as discussed earlier, and Kahn's definition of engagement. The preceding discussion necessitates the need to further empirically investigate identification (Hakanen \& Roodt, 2010). This will be conducted by comparing dedication, work engagement and work-based identity (identification with various facets of work) when using the same set of predictors (resources and demands).

This study then aims to make a contribution towards the understanding of identification, and thus perhaps gain more understanding on the dedication dimension of work engagement. Because dedication is described as identification and involvement, the question may be asked: Is work-based identity distinct from dedication and distinct from work engagement?

Based on this, the following research objectives drive this study:
- Compare overall work engagement, dedication only (subscale of work engagement) and work-based identity.

- To establish whether the JD-R model (Bakker \& Demerouti, 2008) that has been used to predict work engagement, can predict work-based identity. The motivation behind using this model is based on the postulation that work-based identity is developed through a complex negotiation process between an individual's personal resources and work characteristics (Kirpal, 2004b). Work characteristics can be divided into two broad categories: job demands and job resources, as postulated in the JD-R model (Xanthopoulou, Bakker, Demerouti, \& Schaufeli, 2007).

There have been numerous studies conducted on work engagement in the South African context (Barkhuizen \& Rothmann, 2008; Fourie, Rothmann \& Van de Vijver, 2008; Mostert, Cronje \& Pienaar, 2006), however, there is very little research done on work-based identity in South Africa. Furthermore, work-based identity has also been regarded as a construct that has 'come of age in organisational literature' due to the changing workplace and its influence on employees (Agostino, 2004, p. 22). The available research on work-based identity has been solely focused on the work identities of employees within first world contexts, namely the European context (e.g. the FAME Consortium in France, Germany and the UK, cited in Dif, 2004) and the American context (Buche, 2003). To date, there has been very little research on the work-based identities of individuals within the African context and specifically the South African context. In addition, very little research has focused on work-based identity and its prediction, except for one study in which role identity and job characteristics were used to predict IT professionals' work identity (Buche, 2003). There is need to 'develop (and test) a series of related hypotheses' on workbased identity (Walsh \& Gordon, 2007, p. 13).

\section{Review of the literature Work engagement}

Work engagement is 'a positive, fulfilling, affectivemotivational state of work-related wellbeing' (Bakker et al., 2008 , p. 188). It is defined and operationalised as 'a positive, fulfilling work-related state of mind that is characterised by vigour, dedication and absorption' (Schaufeli et al., 2002, p.74). Vigour is characterised by high levels of energy and mental resilience; dedication is experienced when individuals are enthusiastic, inspired and challenged whilst doing their work; and absorption is characterised by being very engrossed in one's work (Bakker et al., 2008, p. 188). Recent research reveals that the main dimensions of work engagement are vigour and dedication (González-Romá et al., 2006). Employees that are engaged experience high levels of energy and strong identification towards their work (Bakker et al., 2008; Bakker \& Demerouti, 2008). They are also better enabled to handle job demands (Schaufeli, Taris \& Van Rhenen, 2009).

Studies on work engagement using the JD-R model as a framework have confirmed that work engagement is mainly 
predicted by job resources, particularly when job demands are high (Bakker, Hakanen, Demerouti, \& Xanthopoulou, 2007). These findings are also supported by South African studies (Mostert, Cronje \& Pienaar, 2006; Rothmann \& Jordaan, 2006). Work engagement also mediates the effects of job resources on organisational commitment (Hakanen, Bakker \& Schaufeli, 2006).

\section{Work-based identity}

The following descriptions may clarify the concept. Work identity has been described as the way individuals define themselves at work (Wrzesniewski \& Dutton, 2001). A further elaboration on the concept has been provided by Witt, Patti and Farmer (2002, p. 488) who view work identity as a 'workrelevant target with which the individual primarily identifies: the occupation or the employing organisation'. Another description that is more inclusive of other components of the work environment is that:

work identities are primarily identification with the work environment, the company, the company's objectives or the work-related activities and tasks which individuals perform that make individual and collective productivity possible.

(Kirpal, 2004a, p. 274)

Kirpal (2004b, p. 202) further elaborated on work-identity that it is a multilayered and a multidimensional. Other descriptions focus more on the 'self'. Buche (2003, p. 10) in her study of IT professionals' work identities describes it as 'a socially constructed representation of an individual's unique self-perception based on his or her interactions within the employment environment'. Buche (2003, p. 4) further argues that work identity addresses 'an employee's self-image ... who they see when they look in a mirror'.

In this study the following theoretical definitions have been used. Walsh and Gordon (2007) define work identity as:

a work-based self-concept, constituted of a combination of organisational, occupational, and other identities that shapes the roles a person adopts and the corresponding ways he or she behaves when performing his or her work.

(Walsh \& Gordon, 2007, p. 2)

The other definition describes work-based identity as 'a multi-identity, multi-faceted and multi-layered construction of the self (in which the self-concept fulfils a core, integrative function), that shapes the roles individuals are involved in, within their employment context' (Lloyd, Roodt \& Odendaal, 2011).

Both of these aforementioned theoretical definitions of workbased identity are grounded in personal identity, social identity theory and identity theory. Both the definitions include the 'self-concept' as being multifaceted (Brewer \& Gardner, 1996). Both definitions also make reference to the roles that individuals adopt and fulfil in their work. This is strongly supported by identity theory (Stets \& Burke, 2000). A third reason for their inclusion in this study is that the work-based self-concept consists of a combination of organisational, occupational and other identities. This is supported by social identity theory and social categorisation theory because individuals identify with categories or groups, such as an organisation, a work team or an occupational group (Ashforth \& Mael, 1989).

Considering these theoretical definitions, work-based identity, due to its multifaceted and multi-identity characteristic, is operationalised by an array of possible indicators which include work centrality, job involvement, organisational identification, person-organisation fit, job and career/occupational identity in this study. In order to understand the importance of each of the abovementioned indicators in work-based identity, we will make use of Kirpal's (2004a) perspective on the dimensions that influence identity formation processes. The three dimensions are structural, social and the individual psychological dimension. These three dimensions have been used to develop a work-based identity prototype.

The structural dimension refers to individual and societal paradigms of work that are influenced and shaped by how work, training systems and patterns of employment are embedded within a country's current and historical culture (Kirpal, 2004a). South Africa's transition from an apartheid regime to democracy has changed the meaning of 'South African' (Distiller, 2008, p. 273). Through labour law reforms, the South African workplace has increased in diversity and placed more emphasis on skill development for the previously disadvantaged race groups.

The social dimension refers to the social interaction that individuals engage in with other individuals (i.e. colleagues and supervisors), groups (i.e. communities of practice, workunits and occupational groups) and/or institutional bodies (i.e. trade unions and professional bodies) (Kirpal, 2004a). The indicators of work-based identity that fall under this social dimension include occupational or career identity and organisational identification.

The individual-psychological dimension specifically focuses on the individual's personal identity orientation. This dimension focuses on the career history and professional development of individuals (Kirpal, 2004a) and it also focuses on how an individual perceives his or her work (Kirpal, 2004a). The indicators of work-based identity that fall under this social dimension include work centrality, job involvement and person-organisation fit.

The literature on work-based identity has been limited in the sense that the focus has been on building existing social identity theory by theoretically examining the development of work identities (Walsh \& Gordon, 2007). There has also been a considerable amount of research conducted on how work identities have changed due to globalisation (Huws, 2006), changing work systems (Baugher, 2003; Brown, 2004; Dif, 2004; FAME Consortium cited in Kirpal, 2004b) and 'employees' responses to structural changes and new modes of socialization at work' (Dif, 2004, p. 305). 


\section{The Job Demands-Resources Model}

The JD-R model attributes employee wellbeing to the characteristics of the work environment (Xanthopoulou et al., 2007). Work characteristics can be divided into two broad categories:

- job demands

- job resources.

The JD-R model is considered to be a better model to predict employee well-being, work engagement and burnout than older type of models, as it can be used to assess any type of job. The older models that have been used included the Job Demands Control Model (Karasek, 1979) and the Effort Reward Imbalance Model (Siegrist, 1996). These models considered only a limited number of job characteristics (Bakker \& Demerouti, 2007; Van den Broeck, Vansteenkiste, De Witte \& Lens, 2008) in comparison to the JD-R model that considers all types of job demands and job resources in predicting work engagement.

Furthermore the JD-R model's strength lies in its ability to understand two parallel processes that influence employee well-being. These include (Hakanen, Bakker, \& Schaufeli, 2006):

- a de-energising process in which job demands exhaust an employee's mental and physical resources, which could lead to burnout and eventually ill health

- a motivational process in which job resources promotes work engagement and could lead to organisational commitment.

Job demands and its relationship with work engagement will be discussed in the following section.

Job demands are defined as those physical, psychological, social or organisational aspects of a job that require sustained physical and/or psychological (cognitive and emotional) effort or skills and are therefore associated with certain physiological and/or psychological costs (Bakker \& Demerouti, 2007, p. 312). As stated earlier, job demands are part of the de-energising process that underlines the JD-R model.

The de-energising process is built on the premises of Hockey's (1997) Compensatory Regulatory-Control (CRC) model which states that stressed employees struggle with protecting their primary performance goals (benefits) in the midst of dealing with increased job demands that require an increased amount of mental effort (costs). An employee's compensatory effort has to be mobilised to deal with this struggle. If the compensatory effort is continuous, then the employee will experience energy loss which could possibly result in burnout and eventually ill-health. This process is associated with physiological and psychological costs, such as increased sympathetic activity, fatigue and motivation loss (Hakanen et al., 2006, p. 498). This process is supported by a cross-lagged longitudinal study conducted on Finnish dentists in which job demands were positively correlated with burnout and depression over a period of three years (Hakanen, Schaufeli \& Ahola, 2008).
Job demands can further be grouped into quantitative and qualitative job demands. Quantitative job demands include time pressure and work overload. Qualitative demands include emotional demands, role ambiguity, role conflict and an unfavourable physical work environment.

Job demands as part of the de-energising process have proven to be the strongest predictors of the exhaustion and cynicism dimensions of burnout (Schaufeli \& Bakker, 2004; Xanthopoulou et al., 2007). This is supported by the proposition that employees who have high job demands with a lack of resources are likely to develop burnout and experience a reduction of engagement respectively (Hakanen, Bakker \& Schaufeli, 2006). This can occur in all kinds of jobs and occupations (Bakker, Demerouti \& Verbeke, 2004). A negative relationship was found between work engagement and job demands; perceived job demands was shown to predict burnout (Fourie, Rothmann \& Van de Vijver, 2008).

Based on the aforementioned discussion, the following research hypothesis is formulated:

- Hypothesis 1: Job demands are negatively related to work engagement.

Currently there is no literature indicating that job demands are correlated with work-based identity. However, we can assume that job demands are negatively correlated to workbased identity based on the premises of Hockey's (1997) CRC model, which was discussed earlier. In support of this, individuals who strongly identify with their work are highly engaged and display dedication, which is the opposite of cynicism - a dimension of burnout (González-Romá et al., 2006). If an employee's compensatory effort has to be continually mobilised to deal with high job demands, it is assumed that identification will lessen and the employee will lean more towards experiencing cynicism. In light of this, the following hypothesis is formulated:

- Hypothesis 2: Job demands are negatively related to work-based identity.

Job Resources, on the other hand, are those physical, psychological, social or organisational aspects of a job that either/or (Schaufeli \& Bakker, 2004):

- reduce job demands and the associated physiological and psychological costs

- are functional in achieving work goals

- stimulate personal growth, learning and development.

As stated earlier, job resources are part of the motivational process that underlines the JD-R model.

In the motivational process, job resources are known to influence employee well-being intrinsically through the fostering of employee growth, learning and development, or extrinsically by helping an employee to achieve his or her work goals (Hakanen et al., 2006). The self-determination theory provides support for this motivational process (Deci, Vallerand, Pelletier \& Ryan, 1991). This theory postulates that if the need for competence, relatedness and autonomy (or 
self-determination) is met in any social context, well-being and increased commitment is enhanced. Thus job resources play a vital role in promoting work engagement and finally organisational commitment.

According to Bakker and Demerouti (2007) job resources are located at an organisational level (e.g. salary, career opportunities, access to resources and job security), at an interpersonal and social relations level (e.g. supervisor and co-worker support, and team climate), at the level of organisation of work (e.g. role clarity and participation in decision making) and at the level of tasks (e.g. skill variety, autonomy, performance feedback and task significance).

Job resources have been found to be the strongest predictors of work engagement (Bakker et al., 2008; Mauno, Kinnunen \& Ruokolainen, 2007; Rothmann \& Jordaan, 2006; Schaufeli \& Bakker, 2004), especially in the presence of high job demands (Bakker et al., 2008; Rothmann \& Jordaan, 2006). Furthermore, empirical evidence indicates that job resources are able to buffer the negative impact of job demands on burnout. Although the buffer effect of job resources will not be addressed as an objective in this study of work-based identity, it has been mentioned, to motivate how important job resources are in achieving employee well-being.

Job resources are also considered to be crucial for employee retention. De Lange, De Witte and Notelaers (2008) found that low work engagement, low job autonomy and low departmental resources predicted employees' leaving their companies and transferring to other companies.

Based on the aforementioned discussion, the following research hypothesis is formulated:

TABLE 1: Biographical and demographical details of the participants ( $n=2429)$.

\begin{tabular}{lll}
\hline Variable & Category & \% \\
\hline Gender & Female & 36.8 \\
& Male & 63.2 \\
Race & Black & 26.3 \\
& White & 44.1 \\
& Coloured & 16.3 \\
Age & Asian/ Indian & 13.3 \\
& 19-29 & 12.0 \\
& 30-39 & 39.5 \\
& 40-49 & 36.1 \\
& 50+ & 12.4 \\
& Management & 18.4 \\
& Operational & 54.9 \\
& Specialist & 26.7 \\
\hline Cegion & Central & 4.90 \\
& Corporate & 24.9 \\
& Eastern & 13.1 \\
& Gauteng Central & 18.5 \\
& North Eastern & 13.8 \\
& Southern & 6.50 \\
& Western & 18.2 \\
& Matric or less & 40.7 \\
& Post-school qualifications & 19.7 \\
& National Diploma/National Higher Diploma & 26.9 \\
& & 12.7 \\
\hline
\end{tabular}

- Hypothesis 3: Job resources are positively related to work engagement.

An employee-employer relationship is usually governed by a formal contract agreement and a psychological contract agreement. These contracts occur within a relationship of exchange between the employee and employer. Social exchange theory aims to draw the link between the role of job resources and this relationship of exchange between the employee and employer. The social exchange perspective is based on the premise that the relationship between an employee and an organisation is built on a transaction of effort and commitment for the benefits of receiving a salary, recognition and organisational support (Blau, 1964; Van Knippenberg, Van Dick \& Tavares, 2007). A social exchange is judged to be one of quality when employee inputs (e.g. work, time and effort) into the relationship is on par or equivalent to the benefits (e.g. salary, promotion and recognition) that the employee receives from the relationship. Individuals then become more motivated to maintain the relationship (Van Knippenberg et al., 2007) and 'the boundaries between the self and other' is blurred and deep structure identification is able to develop (Rousseau, 1998, p. 222). Deep structure identification is a form of identification in which 'cognitive schema formed in work settings across roles, over time, and across situations that leads to congruence between self-at work and one's broader self concept' (Turner, 1978 cited in Rousseau, 1998, p. 218).

Based on the aforementioned discussion, the following research hypothesis is formulated:

- Hypothesis 4: Job resources are positively related to work-based identity.

\section{Research design Research approach}

The study follows the quantitative research tradition. A cross-sectional field survey was used to generate the primary data in this study. Correlational data analysis techniques were applied in conducting the data analysis in order to explain relationships between variables on a retrospective basis which typifies this research as ex post facto research.

\section{Research method}

The research method will be discussed under the following four sub-headings.

\section{Research participants and sampling}

A census-based survey ${ }^{1}$ was conducted on the population of employees $(N=23134)$ who were in the employment of an Information and Communications Technology (ICT) sector company in South Africa. A response rate of $10.5 \%$ yielded a sample of 2429 research participants. The biographic and demographic characteristics of the sample are provided in Table 1.

It has been indicated that most respondents are White, Afrikaans or English speaking, male, married or cohabitating,

1.A type of survey where everyone in the target population has an equa chance to participate in the survey. 
in possession of academic qualifications higher than matric (grade 12), and working in either operational or specialist vocational applications (see Table 1).

\section{Measuring instruments}

Demographic particulars of the participants were captured in the company's IT system used for conducting the survey.

The job demands and job resources were measured with several instruments. Most of the job demands and job resources were measured with the 42-item Job Demands-Resources Scale (JDRS) that was developed by Rothmann, Mostert and Strydom (2006). The following job demands (overall internal consistency was 0.81 ) were included in the instrument with accompanying internal consistency reliabilities.

Job insecurity was measured with 3 items that were adapted from the JDRS; examples of the job insecurity items include 'How secure are you that you will still be working in one year's time?' and 'How secure are you that you will keep your current job in the next year?'. The internal consistency reported for the scale in this study is 0.90 .

Overload was measured with 8 items that were adapted from the JDRS; examples of the overload items include 'How often do you have too much work to do?' and 'How frequently do you work under pressure?'. The internal consistency reported for the scale in this study is 0.78 .

Work-family conflict was measured with a work-family conflict scale that was adapted from Netemeyer, Boles and McMurriam (1996); examples of the work-family conflict items include 'How much do the demands of your work interfere with your home and family life?' and 'How often does your job put so much strain on you that you find it difficult to fulfil family duties?'. The internal consistency reported for the scale in this study is 0.96 .

The following job resources (overall internal consistency was 0.94) were included in the study:

- advancement

- growth opportunities

- organisational support

- perceived external prestige

- task identity

- team climate

- work-based identity.

Advancement was measured with 6 items that were adapted from the JDRS; examples of the advancement items include 'How good do you think your organisation's salaries are?' and 'To what extent does your job offer you the possibility to progress financially?'. The internal consistency reported in this study is 0.83 .

Growth opportunities were measured with 7 items that were adapted from the JDRS; examples of the growth opportunities items are include 'How much variety do you have in your work?' and 'And how much direct influence do you have on the decisions made by your organisation?'. The internal consistency reported for the scale in this study is 0.84 .

Organisational support was measured with 18 items that were adapted from the JDRS; examples of organisational support items are include 'How much can you count on your colleagues when you come across difficulties in your work?' and 'How often if necessary, can you ask your colleagues for help?'. The internal consistency reported for this scale in this study is 0.91 .

Perceived external prestige was measured with 5 items that were adapted from Riordan, Gatewood and Bill (1997); examples of perceived external prestige items are include 'Generally, how good is (Company X's) reputation in the community?' and 'Generally, how good is (Company X's) reputation in the industry?'. The Cronbach alpha reported is 0.90 .

Task identity was measured with 2 items that were adapted from Hackman and Oldham (1975). The two items are include 'To what extent is your job arranged so that you have the chance to do an entire piece of work from beginning to end?' and 'How often does the job provide you the chance to completely finish the pieces of work you begin?'. The Cronbach alpha reported for this scale in this study is 0.89 .

Team climate was measured with 6 items that were adapted from Klivimaki and Elovaino (1999); examples of the team climate items include 'How free do you feel to share ideas for improvement in your division?' and 'How effectively organized is your division to support quality service?'. The internal consistency reported for this scale in this study is 0.89 .

Work-based identity was measured with a number of scales that measured its facets or indicators, which include:

- work centrality

- person-organisation-fit

- organisational identification

- job

- career

- occupation

- work.

Work-based identity was operationalised this way, as there were no suitable measurements found that complied with the requirements of the theoretical definition of work-based identity. A 7-point intensity response scale was developed which was anchored at extreme poles.

The work-based identity scale initially consisted of 36 items compiled as follows.

Nineteen items were selected from a scale of Roodt (1997) that loaded on the sub scales labelled 'workaholism', 'organisational-related involvement or commitment' and 'work-related alienation'.

Workaholism showed a strong orientation towards the value of work or work centrality. The scale consists of 11 items 
and include examples such as 'To what extent do you regard work as the most important aspect in your life?' and 'How much meaning does work add to your life?'.

Five items were selected from organisational-related involvement/commitment, including 'How much do you see your job as your whole life?' and 'How much do you give to your job?'.

Three items were selected from work-related alienation; examples of the selected items include 'How much does your work determine your value as a person?' and 'To what extent does your job allow for the achievement of personal goals?'.

One item was selected from the Lodahl and Kejner (1965) Job Involvement Scale namely 'How likely are you to regard your work as only a small part of who you are?'.

Five items were selected from three subscales from The Functions of Identity Scale of Serafini, Maitland and Adams (2006), namely:

- structure ('the structure of understanding of who one is')

- goals ('meaning and direction through commitments, values and goals')

- future ('to what extent do you feel that your work values and beliefs reflect who you are?').

The resulting Cronbach's alpha was 0.82 . Items selected from this subscale were eventually dropped from the questionnaire after factor analysis (see Results section).

Organisational identification was assessed with the 6-item scale from Mael and Ashforth (1992). Some of the adapted items included "How often do you say "we" rather than "they" when you talk about the organisation that you work for?' and 'How interested are you in what others think about the organisation that you work for?'. A Cronbach Alpha of 0.88 was reported in this study.

Person-Organisation-fit was measured with 3 items from the Person-Organisation-fit Scale of Lauver and Kristof-Brown (2001); examples of the selected items include 'To what degree do your values match or fit the values of the organisation that you work for?' and 'To what degree are you able to maintain your values at the organisation that you work for?'. A Cronbach alpha of 0.81 was reported for this scale.

All the items of the work-based identity scale were measured on a 7-point intensity response scale anchored at extreme poles (e.g. 'Highly unlikely' 1 - low intensity to 'Highly likely' 7 - high intensity). Participants were asked to use the measuring scale to indicate the degree to which their answers accurately describe their own situation and feelings by clicking on the appropriate radio buttons.

\section{Reliability and validity of the instrument}

The 36-item questionnaire was factor analysed on a first and second level to determine the factor structure. This resulted in the creation of the 28-item, uni-dimensional Work-based Identity scale (Roodt, De Braine, Bothma \& Jansen, 2009).

\section{Work engagement}

The Utrecht Work Engagement Scale (UWES) was used to measure work engagement. The 17-item scale is composed of three subscales namely vigour (six items) with Cronbach alphas ranging from 0.75 to 0.82 (Schaufeli \& Bakker, 2004), dedication (five items) with Cronbach alphas ranging from 0.88 to 0.90 (Schaufeli \& Bakker, 2004) and absorption (six items) with Cronbach alphas ranging from 0.70 to 0.75 (Schaufeli \& Bakker, 2004); examples of the items include:

- 'At my work, I feel bursting with energy' (vigor)

- 'I am enthusiastic about my job' (dedication)

- 'When I am working, I forget everything else around me' (absorption).

The internal consistency reported for vigour was 0.85 , for dedication 0.91 and for absorption 0.85 .

All the items of the survey, except for the UWES scale, were measured on a 7-point intensity response scale anchored at extreme poles (e.g. 'Highly unlikely' 1 - low intensity to 'Highly likely' 7 - high intensity).

\section{Research procedure}

An e-invitation letter was sent out to all permanent employees, up to middle management of the ICT sector company. The invitation included a web-link for access to the survey. The survey was constructed in such a manner that participants could complete individual sections of the survey, one section at a time, before submitting their final response.

\section{Statistical analysis}

The SPSS programme was used to conduct the statistical analysis (Pallant, 2005). The following statistical techniques were used:

- factor and reliability analyses

- Pearson correlations

- general multiple regression models.

The multiple regression models included individual job resources and job demands variables for predicting both work-based identity and work engagement.

\section{Results}

\section{Factor and reliability analyses}

All the scales were subjected to a factor and reliability analysis. Item scores were inter-correlated and these matrices were subjected to the Kaiser-Meyer-Olkin and Bartlett's tests for suitability for factor analyses. Single factor structures were obtained for all scales and acceptable reliabilities were obtained for all subscales and for the overall scales.

The KMO-MSA values for the work-based identity, work engagement, job demands and job resources exceeded the recommended value of 0.60 (Tabachnick \& Fidell, 2007). This indicated that the scales were suitable for factor analysis (Hair, Anderson, Tatham \& Black, 1998). 
Work-based identity, work engagement, job demands and job resources scales each underwent first and second level factor analysis. The principal axis factoring method was used. This was then followed by an Oblimin rotation and by a scree test. All scales and subscales yielded a single factor structure where all items loaded onto the particular scale.

Additional second-level factor analyses were conducted on the subscales of work engagement, job demands and job resources. The same procedure was repeated for the secondlevel factor analyses, but in this case only the total scores of the subscales were intercorrelated. For the work engagement scale a single factor was extracted and it yielded an overall Cronbach Alpha of 0.91 .

Two factors were extracted from the work-based identity scale. The second factor (called future) was omitted from further analyses as this factor was nondetermined. Only 28 items of the first factor (called work-based identity) were retained and it yielded a Cronbach Alpha of 0.95 (Roodt, De Braine, Bothma \& Jansen, 2009).

The reliability coefficients for the scales' work-based identity, work engagement, job demands and job resources were all above the acceptable level of 0.70 (see Table 2), indicating that they measured single one-dimensional latent constructs. All the scales were treated as one-dimensional scales.

The scales and subscales' reliabilities and intercorrelations between the overall scales on the different scales are reported in Table 2.

It is clear from Table 2 that all the scales have acceptable reliabilities. Job resources demonstrate much higher correlations with work-based identity, work engagement and its subscales than job demands.

Work engagement and work-based identity were found to be positively and significantly related to one another, thereby indicating that these two constructs share about $50 \%$ common variance.

\section{Multiple regression analyses}

The next analysis took the form of multiple regression analyses in which job demands and job resources served as predictors of work engagement (as measured by the UWES), of dedication (a dimension of work engagement also measured by the UWES); and of work-based identity (as measured by various scales) respectively.

The results of the multiple regression analysis with job demands and job resources as independent variables and work-engagement as dependent variable is reported in Table 3 .

Results of regression analysis in predicting workengagement by job demands and job resources

The results for job demands and job resources were similar when using two random split samples for work engagement. The results of the multiple regression analysis with job demands and job resources as independent variables and dedication (a subscale of work-engagement) as dependent variable is reported in Table 4.

\section{Results of regression analysis in predicting the dedication} subscale of work engagement by job demands and job resources

The results for job demands and job resources were similar when using one random sample for dedication. The results of the multiple regression analysis with job demands and job resources as independent variables and work-based identity as dependent variable is reported in Table 5 .

\section{Results of regression analysis in predicting work-based} identity by job demands and job resources

The results for job demands and job resources were similar when using two random split samples to the full sample for work-based identity.

\section{Discussion}

The study aimed to make a contribution towards the understanding of identification, and thus perhaps gain more understanding on the dedication dimension of work engagement. A further aim of this study is to establish whether the JD-R model that has been used to predict work engagement, can predict work-based identity. The study makes an important contribution by comparing both work-based identity and work engagement as a criterion. The results of the study make an important theoretical contribution in this respect as no results were reported in previous studies.

TABLE 2: Mean, Standard Deviations, Internal Consistencies (Cronbach $\alpha$ 's on the Diagonal), and Correlations amongst the Variables $(N=2429)$.

\begin{tabular}{|c|c|c|c|c|c|c|c|c|c|}
\hline Variables & $M$ & SD & 1 & 2 & 3 & 4 & 5 & 6 & 7 \\
\hline 1. Job Demands & 4.01 & 0.80 & 0.81 & - & - & - & - & - & - \\
\hline 2. Job Resources & 4.47 & 0.90 & $0.125^{* *}$ & 0.94 & - & - & - & - & - \\
\hline 3. Work Engagement & 4.50 & 1.23 & $0.160^{* *}$ & $0.549 * *$ & 0.95 & - & - & - & - \\
\hline 4. Vigor & 4.58 & 1.22 & $0.102 * *$ & $0.524^{* *}$ & - & 0.85 & - & - & - \\
\hline 5. Dedication & 4.44 & 1.47 & $0.139 * *$ & $0.583^{* *}$ & $0.583^{* *}$ & $0.858^{* *}$ & 0.91 & - & - \\
\hline 6. Absorption & 4.47 & 1.04 & $0.205^{* *}$ & $0.440 * *$ & - & $0.794^{* *}$ & $0.795^{* *}$ & 0.85 & - \\
\hline
\end{tabular}


TABLE 3: Results of regression analysis in predicting work-engagement by job demands and job resources.

\begin{tabular}{lllll}
\hline Variable & B & SEB & $\boldsymbol{\beta}$ & $\boldsymbol{p}$ \\
\hline Constant & 0.638 & 0.140 & - & 0.000 \\
Job demands & 0.142 & 0.026 & 0.093 & 0.000 \\
Job resources & 0.737 & 0.023 & 0.538 & 0.000 \\
$R=0.557$ a & - & - & - & - \\
$R^{2}=0.310$ & - & - & - & - \\
$\Delta R^{2}=0.310$ & - & - & - & - \\
\hline
\end{tabular}

$B$, Unstandardised coefficient and constant for the linear regression equation; SEB, Standard Error of $\mathrm{B} ; \beta$, The standardised regression coefficient; $p$, probability value.

$N=2429$.

TABLE 4: Results of regression analysis in predicting the dedication sub-scale of work-engagement by job demands and job resources.

\begin{tabular}{lllll}
\hline Variable & B & SEB & $\boldsymbol{\beta}$ & $\boldsymbol{p}$ \\
\hline Constant & -0.227 & 0.162 & - & 0.161 \\
Job demands & 0.122 & 0.030 & 0.067 & 0.000 \\
Job resources & 0.935 & 0.027 & 0.575 & 0.000 \\
$R=0.587$ a & - & - & - & - \\
$R^{2}=0.345$ & - & - & - & - \\
$\Delta R^{2}=0.344$ & - & - & - & -
\end{tabular}

B, Unstandardised coefficient and constant for the linear regression equation; SEB, Standard Error of $B ; \beta$, The standardised regression coefficient; $p$, probability value. $N=2429$.

TABLE 5: Results of regression analysis in predicting work-based identity by job demands and job resources work-engagement by job demands and job resources.

\begin{tabular}{lllll}
\hline Variable & B & SEB & $\boldsymbol{\beta}$ & $\boldsymbol{p}$ \\
\hline Constant & 1.263 & 0.111 & - & 0.000 \\
Job demands & 0.123 & 0.021 & 0.095 & 0.000 \\
Job resources & 0.700 & 0.018 & 0.605 & 0.000 \\
$R=0.624$ a & - & - & - & - \\
$R^{2}=0.389$ & - & - & - & - \\
$\Delta R^{2}=0.389$ & - & - & - & - \\
\hline
\end{tabular}

$B$, Unstandardised coefficient and constant for the linear regression equation; SEB, Standard Error of $B ; \beta$, The standardised regression coefficient; $p$, probability value.

$N=2429$

\section{Main findings}

In terms of the first research objective to compare overall work engagement, dedication (subscale of work engagement) only and work-based identity, regression analysis was performed. Job demands yielded a higher Beta weight in work-based identity than in dedication alone or in work engagement combined. Job resources yielded a higher Beta weight in work-based identity than in dedication alone or in work engagement combined. No previous studies could shed light on these findings. The JD-R model explained substantively more variance in work-based identity, than dedication alone and work engagement combined. Job demands and resources elicited a slightly stronger $R^{2}$ with dedication than with work engagement (but the regression with work-based identity elicited the highest $R^{2}$ ). This raises the question, what do the other two dimensions (vigour and absorption) contribute towards explaining work engagement? This has consequences for the conceptualisation and operationalisation of work engagement.

Job resources' standard Beta coefficients increases from engagement, through dedication to the highest value in workbased identity whilst the coefficients for job demands is the lowest for dedication and virtually identical for engagement and work-based identity.

It was expected that job demands will be negatively related to work engagement. Job demands did not report a negative relationship with work engagement. This result contradicts the general postulate that job demands are negatively related to work engagement. It was found in this study that job demands have a weak relationship with work engagement. This is in line with previous studies (Fourie et al., 2008; Hakanen et al., 2008). This result is not unexpected in situations where there is an abundance of resources (Bakker \& Demerouti, 2007).

Furthermore, job demands were expected to be negatively related to work-based identity. It was found in the study that job demands have a weak relationship with work based identity. This may be due to the participants having many job resources at their disposal, thus lessening the possible negative effects that job demands can bring.

The results confirmed that job resources are positively related to work engagement. This finding for work engagement is supported by previous research (Bakker et al., 2007). Job resources are known to lead to more engagement (Schaufeli \& Bakker, 2004). They further state that increasing job resources should be used to combat the effects of high job demands, as job resources have been proven to lower the effect of turnover intention and burnout.

The results confirmed that job resources are positively related to work-based identity. Job resources emerged as the most important predictor of work-based identity as opposed to job demands. This finding also clearly supports the notion that job resources as a work characteristic plays a significant role in work identification (Kirpal, 2004b). The finding also supports the notion that when individuals view the social exchange relationship with their organisation as favourable, the 'boundaries between the self and other' are blurred and deep structure identification is able to develop (Rousseau, 1998, p. 222) thus enabling strong work identification.

\section{Managerial implications and recommendations}

The results imply that managers should place a greater emphasis on increasing job resources as it predicts work engagement and work-based identity. The findings of the study also provide support for the use of the JD-R model as a human resource management tool for the improvement of employee well-being and performance (Bakker \& Demerouti, 2007; Hakanen et al., 2008), and for building of strong work identities (Kirpal, 2004a).

\section{Limitations of the study}

The first limitation of the study is the use of a cross sectional design in which relationships between variables cannot be interpreted causally. Another limitation is that this study did not take into account the personal resources (e.g. self-efficacy, optimism and organisational based self-esteem) as possible predictors of work-based identity. These personal resources 
were found to mediate the relationship between job resources and engagement or exhaustion. They also influence the way job resources are perceived (Xanthopoulou et al., 2007).

\section{Suggestions for future research}

Future research should therefore examine the role of job resources and demands in predicting work-based identity. A cross-lagged panel design study on the prediction of organisational commitment including the JD-R model and both work-based identity and work engagement as predictors, would be useful to determine how work-based identity and work engagement interact over time in predicting organisational commitment and which one precedes the other. Work engagement should also be conceptually and empirically revisited.

\section{Conclusion}

Overall the JD-R model explained substantively more variance in work-based identity, than dedication alone and work engagement combined. Work-based identity was shown to be a different construct to the dedication (identification-based component of work engagement) and work engagement. This study has also proven that workbased identity can be predicted using the JD-R model.

In conclusion, work engagement should be both conceptually and empirically revisited, as the JD-R model showed more variance in predicting dedication than work engagement, although it is regarded as 'a well defined and properly operationalised psychological state that is open to empirical research and practical application' (Leiter \& Bakker, 2010, p. 2).

\section{References}

Agostino, J. (2004). Workplace Identity. Doctoral Thesis. Hawthorn, Victoria, Australia: Australian Graduate School of Entrepreneurship.

Ashforth, B.E., \& Mael, F. (1989). Social identity theory and the organisation. Academy of Management Review, 14(1), 20-40. doi:10.2307/258189

Bakker, A.B., \& Demerouti, E. (2007). The Job Demands-Resources model: state of the art. Journal of Managerial Psychology, 22(3), 309-328. doi:10.1108/02683940710733115

Bakker, A.B., \& Demerouti, E. (2008).Towards a model of work engagement. Caree Development International, 13(3), 209-223. doi:10.1108/13620430810870476

Bakker, A.B., Demerouti, E., \& Verbeke, W. (2004). Using the Job Demands-Resources model to predict burnout and performance. Human Resource Management 43(1), 83-104. doi:10.1002/hrm.20004

Bakker, A.B., Hakanen, J.J., Demerouti, E., \& Xanthopoulou, D. (2007). Job resources boost work engagement, particularly when job demands are high. Journal of Educational Psychology, 99(2), 274-284. doi:10.1037/0022-0663.99.2.274

Bakker, A.B., Schaufeli, W.B., Leiter, M.P., \& Taris, T.W. (2008). Work engagement: An emerging concept in occupational psychology. Work \& Stress, 22(3), 187-200.

Bakker, A.B., \& Leiter, M.P. (2010). Where to go from here: Integration and future research on work engagement. In A.B. Bakker \& M.P. Leiter (Eds.). Work Engagement, A Handbook of Essential Theory and Research (pp.181-196). Great Britain: Psychology Press.

Barkhuizen, N., \& Rothmann, S. (2008). Occupational stress of academic staff in South African higher education institutions. South African Journal of Psychology, 38(2), 321-336.

Baugher, J.E. (2003). Caught in the middle? Worker identity under new participatory roles. Sociological Forum, 18(3), 417-439. doi:10.1023/A:1025717619065

Blau, P.M. (1964). Exchange and power in social life. New York: Wiley.

Brewer, M.B., \& Gardner, W. (1996). Who is this "we"? Levels of collective identity and self-representation. Journal of Personality and Social Psychology, 71, 83-93. doi:10.1037/0022-3514.71.1.83
Brown, A. (2004). Engineering Identities. Career Development International, 9(3), 245-273. doi:10.1108/13620430410535841

Buche, M.W. (2003). IT Professional Work Identity: Construct and Outcomes. Dissertation. USA: University of Kansas.

Deci, E.L., Vallerand, R.J., Pelletier, L.G., \& Ryan, R.M. (1991). Motivation and education: The self-determination perspective. Educational Psychology, 26 , 325-355. doi:10.1207/s15326985ep2603\&4_6

De Lange, A.H., De Witte, H., \& Notelaers, G. (2008). Should I stay or should I go? Examining longitudinal relations among job resources and work engagement for stayers versus movers. Work \& Stress, 22(3), 201-223. doi:10.1080/02678370802390132

Dif, M. (2004). Vocational identities in change in the telecommunications sector. Career Development International, 9(3), 305-322. doi:10.1108/13620430410535869

Distiller, N. (2008). Surviving the future. Towards a South African cultural studies. Cultural Studies, 22(2), 273-283. doi:10.1080/09502380701789182

Fourie, L., Rothmann, S., \& Van de Vijver, F.J.R. (2008). A model of work wellness for non-professional counsellors in South Africa. Stress and Health, 24, 35-47. doi:10.1002/smi.1163

González-Romá, V., Schaufeli, W.B., Bakker, A.B., \& Lloret, S. (2006). Burnout and work engagement: Independent factors or opposite poles? Journal of Vocational Behavior, 68, 165-174. doi:10.1016/j.jvb.2005.01.003

Hackman, J.R., \& Oldham, G.R. (1975). Development of the Job Diagnostic Survey, Journal of Applied Psychology, 60(2), 159-170. doi:10.1037/h0076546

Hair, J.F., Anderson, R.E., Tatham, R.L. \& Black, W.C. (1998). Multivariate data analysis, (5 edn.). Upper Saddle River, N.J: Prentice-Hall International.

Hakanen, J.J., Bakker, A.B., \& Schaufeli, W.B. (2006). Burnout and work engagement among teachers. Journal of School Psychology, 43, 495-513. doi:10.1016/j. jsp.2005.11.001

Hakanen, J.J., \& Roodt, G. (2010). Using the job demands-resources model to predict engagement: Analysing a conceptual model. In A.B. Bakker, \& M.P. Leiter, (Eds.). Work Engagement, A Handbook of Essential Theory and Research (pp.85-101). Great Britain: Psychology Press.

Hakanen, J.J., Schaufeli, W.B., \& Ahola, K. (2008). The Job Demands-Resources model: A three year cross-lagged study of burnout, depression, commitment and work engagement. Work \& Stress, 22(3), 224-241.

Halbesleben, J.R.B. (2010). A meta-analysis of work engagement: Relationships with burnout, demands, resources, and consequences. In A.B. Bakker \& M.P. Leiter (Eds.), Work Engagement. A Handbook of Essential Theory and Research (pp.102-117). Great Britain: Psychology Press.

Hockey, G.R.J. (1997). Compensatory control in the regulation of human performance under stress and high workload: A cognitive-energetical framework, Biological Psychology, 45, 73-93. doi:10.1016/S0301-0511(96)05223-4

Kahn, W.A. (1990). Psychological conditions of personal engagement and disengagement at work. Academy of Management Review, 33(4), 692-724. DOI:10.2307/256287

Kahn, W.A. (1992). To be fully there: psychological presence at work. Human Relations, 45(4), 321-349. doi:10.1177/001872679204500402

Kanungo, R. N. (1982). Measurement of job and work involvement. Journal of Applied Psychology, 67 (3), 341-349. doi:10.1037/0021-9010.67.3.341

Karasek, R. (1979). Job demands, job decision latitude, and mental strain. Implications for job redesign. Administrative Science Quarterly, 24, 285-308. doi:10.2307/2392498

Kirpal, S. (2004a). Work identities of nurses. Between caring and efficiency demands. Career Development International, 9(3), 274-304. doi:10.1108/13620430410535850

Kirpal, S. (2004b). Researching work identities in a European context. Career Development Journal, 9(3), 199-221. doi:10.1108/13620430410535823

Klivimaki, M., \& Elovainio, M. (1999). A short version of the team climate inventory, development and psychometric properties. Journal of Occupational and Organisational Psychology, 72, 241-246. doi:10.1348/096317999166644

Lauver, K.J., \& Kristof-Brown, A. (2001). Distinguishing between employee's perceptions of person-job and person-organization fit. Journal of Vocational perceptions of person-job and person-organization fit
Behavior, 59(3), 454-470. doi:10.1006/jvbe.2001.1807

Leiter, M.P., \& Bakker, A.B. (2010). Work engagement: Introduction. In A.B. Bakker \& M.P. Leiter (Eds.). Work Engagement. A Handbook of Essential Theory and Research (pp.1-9). Great Britain: Psychology Press.

Lloyd, S., Roodt, G., \& Odendaal, A. (In Press). Critical elements in defining workbased identity in a post apartheid South Africa. South African Journal of Industrial Psychology/SA Tydskrif vir Bedryfsielkunde.

Lodahl, T.M., \& Kejner, M. (1965). The definition and measurement of job involvement. Journal of Applied Psychology, 49(1), 24-33. DOI:10.1037/ h0021692, PMid:14279757

Mael, F.A., \& Ashforth, B.E. (1992). Alumni and their alma: A partial test of the reformulated model of organizational identification. Journal of Organizational Behavior, 13(2), 103-123. doi:10.1002/job.4030130202

Mauno, S., Kinnunen, U., \& Ruokolainen, M. (2007). Job demands and resources as antecedents of work engagement: A Longitudinal Study. University of Jyvaskla, Department of Psychology, Finland; University of Tampere, Department of Psychology, Finland.

Mostert, K., Cronje, S., \& Pienaar, J. (2006). Job resources, work engagement and the mediating role of positive work-home interaction of police officers in the NorthWest province. Acta Criminologica, 19(3), 64-87. 
Netemeyer, R.G., Boles, J.S., \& McMurriam, R. (1996). Development and validation of work-family conflict and family-work conflict scales. Journal of Applied Psychology, 81, 400-410. doi:10.1037/0021-9010.81.4.400

Pallant, J. (2005). Survival Manual Second Edition: A Step By Step Guide to Dato Analysis. (12th edn.). New York: Open University Press.

Riordan, C.M., Gatewood, R.D., \& Bill, J.B. (1997). Corporate Image: Employee reactions and implications for managing corporate social performance. Journal of Business Ethics, 16(4), 401-412. doi:10.1023/A:1017989205184

Roodt, G. (1997). Theoretical and empirical linkages between work-related commitment foci. South African Journal of Industrial Psychology/SA Tydskrif vir Bedryfsielkunde, 23(2), 6-13.

Roodt, G., De Braine, R., Bothma, F.C., \& Jansen, P.G. (2009). The Work-based Identity Questionnaire. Unpublished questionnaire. University of Johannesburg.

Rothmann, S., \& Jordaan, G.M.E. (2006). Job demands, job resources and work engagement of academic staff in South African higher education institutions. South African Journal of Industrial Psychology/SA Tydskrif vir Bedryfsielkunde, 32(4), 87-96.

Rothmann, S., Mostert, K., \& Strydom, M. (2006). A psychometric evaluation of the job demands resources scale in South Africa. South African Journal of Industrial Psychology/SA Tydskrif vir Bedryfsielkunde, 32(4), 76-86.

Rousseau, D.M. (1998). Why workers still identify with organisations? Journal of Organisational Behaviour, 19, 217-233. doi:10.1002/(SICI)10991379(199805)19 :3<217::AID-JOB931>3.0.CO;2-N, doi:10.1002/(SICI)10991379(199805)19:3<217 :AID-JOB931>3.3.CO;2-E

Schaufeli, W.B., \& Bakker, A.B. (2004). Job demands, job resources and their relationship with burnout and engagement: a multi-sample study. Journal of Organisational Behavior, 25, 293-315. doi:10.1002/job.248

Schaufeli, W.B., Salanova, M., González-Romá, V., \& Bakker, A.B. (2002). The measurement of engagement and burnout: A two sample confirmatory factor analytic approach. Journal of Happiness Studies, 3, 71-92. doi:10.1023/A:1015630930326

Schaufeli, W.B., Taris, T.W., \& Van Rhenen, W. (2009). Workaholism, burnout and work engagement: Three of a kind or three different kinds of employee wellbeing. engagement: Three of a kind or three different kinds of empl
Applied Psychology: An International Review, 57(2), 173-203.
Serafini, T.E., Maitland, S.B., \& Adams, G.R. (2006). The Functions of Identity Scale: Revisions, validation and model testing. Retrieved May 02, 2008, from w3.fiu.edu/ Revisions, validatio
srif/.../Serafini/

Shirom, A. (2004). Feeling vigorous at work? The construct of vigor and the study of positive affect in organisations. In D.G.P.L Perrewe (Ed.). Research in organisational positive affect in organisations. In D.G.P.L Perrewe (Ed.). Research in orgd
stress and wellbeing (Vol. 3, pp.135-165). Greenwich, CN: JAI Press.

Siegrist, J. (1996). Adverse health effects of high effort-low reward conditions. Journa of Occupational Health Psychology, 1, 27-41. doi:10.1037/1076-8998.1.1.27

Simpson, M.R. (2008). Engagement at work: A review of the literature. International Journal of Nursing Studies. doi:10.1016/j.ijnurstu.2008.05.003.

Stets, J., \& Burke, P.J. (2000). Identity theory and social identity theory. Socia Psychology Quarterly, 63(3), 224-237. doi:10.2307/2695870

Tabachnick, B.G. \& Fidell, L. S. (2007). Using multivariate statstics. (5th edn.). Boston: Pearson Education.

Van den Broeck, A., Vansteenkiste, M., De Witte, H., \& Lens, W. (2008). Explaining the relationships between job characteristics, burnout, and engagement: The role of basic psychological need satisfaction. Work \& Stress, 22(3), 277-294. doi:10.1080/02678370802393672

Van Knippenberg, D., Van Dick, R., \& Tavares, S. (2007). Social identity and social exchange: Identification, support, and withdrawal from the job. Journal of Applied Social Psychology, 37, 457-477. doi:10.1111/j.1559-1816.2007.00168.x

Walsh, K., \& Gordon, J.R. (2007). Creating an individual work identity. Human Resource Management Review, 1-16.

Witt, L.A., Patti, A.L., \& Farmer, W.L. (2002). Organisational politics and work identity as predictors of organisational commitment. Journal of Applied Psychology, 32(3), as predictors of organisational commitment. Journal

Wrzesniewski, A., \& Dutton, J.E. (2001). Crafting a job: Revisioning employees' as active crafters of their work. Academy of Management Review, 26(2), 179-201. doi: $10.2307 / 259118$

Xanthopoulou, D., Bakker, A.B., Demerouti, E., \& Schaufeli, W.B. (2007). The role of personal resources in the job demands-resources model. International Journal of Stress Management, 14, 121-141. doi:10.1037/1072-5245.14.2.121 